\section{Case Report}

J Immunol Clin Microbiol 2016; 1(2):45-47

DOI: $10.5455 /$ jicm.2016.1.224190

\title{
Soft tissue infections due to human bites
}

\author{
Fatma Meral Ince $^{1 *}$, Emel Aslan${ }^{1}$, Özcan Deveci ${ }^{1}$, Recep Tekin ${ }^{1}$ \\ ${ }^{1}$ Dicle University Faculty of Medicine, Department of Infectious Diseases and Clinical Microbiology, Diyarbakir Turkey
}

\begin{abstract}
Background: Human bites are potentially dangerous wounds constituting an important cause of morbidity. Infections caused by human bites are reported to be more severe than infections caused by animal bites. The aim of this article is to present two patients with soft tissue infections secondary to human bites, which are rare in the literature.

Case presentation: The first patient is a 62-year old female whose $4^{\text {th }}$ digit of her left hand was bitten by her disabled child and became necrotic. The second patient is a 35-year old female patient whose $2^{\text {nd }}$ digit in her left hand was bitten by her husband five days ago. Both patients had undergone debridement for the necrotic infections in the area of the lesion and prescribed the appropriate antibiotherapy. Rest, elevation and immobilization were maintained. The reconstruction and physiotherapy gave satisfactory results.

Conclusion: Human bite wounds have long had a bad reputation for severe infection and frequent complication. For this reason, prophylactic antibiotic treatment should be given after human bite to prevent infection. If the infection signs and symptoms develop, rapid diagnosis, appropriate antibiotic and surgical therapy should be applied instantly.

Key words: Human bite, soft tissue infection, debridement
\end{abstract}

\section{Introduction}

Human bites are relatively rare; they are the injuries with the greatest risk (\%10-50) for the development of infections (1). Infections secondary to human bite are reported to be more dangerous compared to animal bites (1-3). While the infection may be caused by the pathogens in the mouth flora of the biter, it may also be caused by the pathogens on the skin of the bitten person (4). The most common bacteria associated with infections secondary to human bites are $\alpha$ and $\beta$ hemolytic streptococci, Staphylococcus aureus, Staphylococcus epidermidis, Corynebacterium spp. and Eikenella corrodens. These two patients with soft tissue infections secondary to human bites are presented in this article since they are interesting cases which are rarely presented in literature.

\section{Case 1}

The 62-year old female patient, whose $4^{\text {th }}$ digit in her left hand was bitten by her disabled child 6 days ago, had initially presented to a healthcare center where her wound was dressed and oral antibiotherapy was prescribed. When her complaints escalated, the patient presented to our clinic. She was admitted to our clinic with the diagnosis of necrotic and infectious wound and soft tissue infection in the $4^{\text {th }}$ digit in her left hand (Figure 1). Since she had a swelling and subcutaneous edema between the necrotic $4^{\text {th }}$ finger towards the dorsal aspect of her hand as well as increased echogenicity in her soft tissues, she was started on a regimen with $4 \times 1.5$ grams of intravenous (IV) ampicillin-sulbactam. During the operation conducted by the department of orthopedics, the patient underwent a debridement and a bacterial culture samples were collected.
*Corresponding Author: Fatma Meral Ince; Dept. of Infectious Diseases and Clinical Microbiology, Dicle University Medical Faculty, Diyarbakir, Turkey. E-mail: drmeralince @ gmail.com Received: March 07, 2016 Accepted:March 17, 2016 Published Online: March 23, 2016
This is an Open Access article distributed under the terms of the Creative Commons Attribution NonCommercial License which permits unrestricted non-commercial use, distribution, and reproduction in any medium, provided the original work is properly cited. 
The patient's left hand was placed in a short splint and elevated. No growth was observed in the wound culture. When the patient had a temperature on the third day of the antibiotherapy, blood cultures were obtained from both her arms and her medication as changed to $3 \times 1$ grams of IV meropenem. The patient's dressings were changed every day. The necrotic tissue on the $4^{\text {th }}$ digit of the patient's left hand was debrided by the Plastic and Reconstructive Surgery department and the wound was dressed. When significant improvement was observed at the wound site (Figure 2) and the infection improved, the patient was discharged on the $12^{\text {th }}$ day of the meropenem therapy with a prescription for oral levofloxacin treatment and a follow up visit by the Plastic and Reconstructive Surgery outpatient clinic scheduled a week later. She was also recommended physiotherapy for hand movements and a home exercise program by the Rehabilitation Department. No sign of local or deep infection was observed during the follow up visits on an outpatient basis.

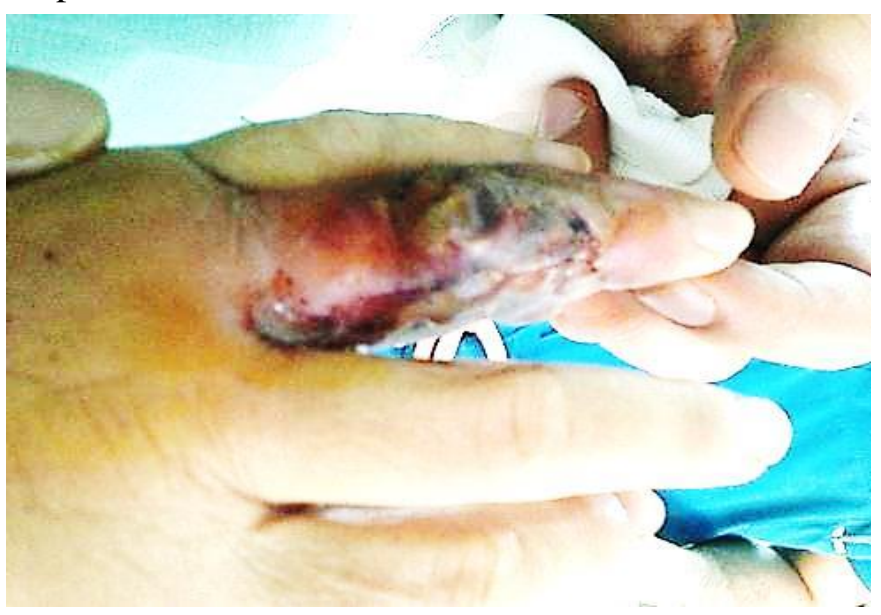

Figure 1. Lesion formed after the bite.

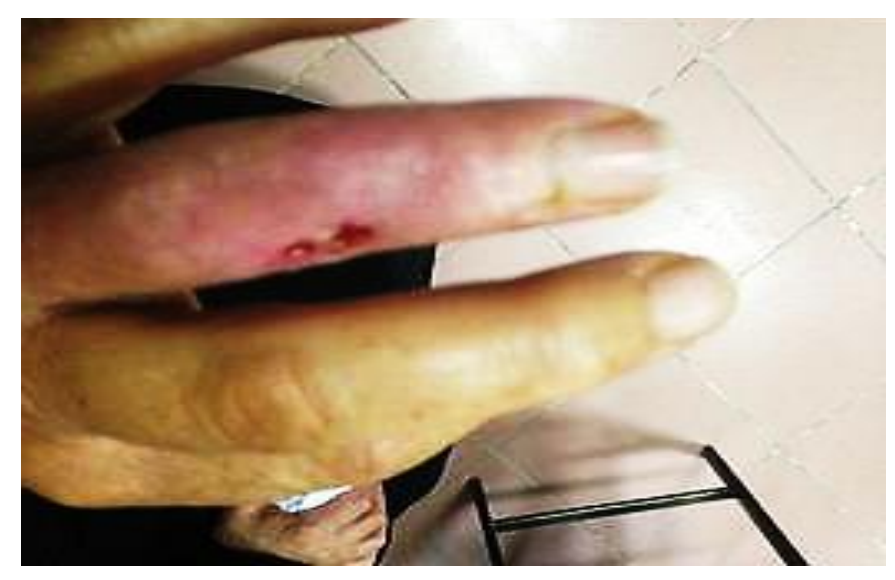

Figure 2. Appearance after the treatment.

\section{Case 2}

A 35-year old female patient whose $2^{\text {nd }}$ digit in her left hand was bitten by her husband five days ago presented to a healthcare center when she observed redness, increased temperature and swelling in the wound area. When her complaints became more severe in spite of the oral ciprofloxacin prescribed at this center, she presented to the emergency room of our hospital. After the debridement performed by the Plastic and Reconstructive Surgery department on the $2^{\text {nd }}$ finger of her left hand, the patient was admitted to our clinic. A cell culture was performed and she was started on $3 \times 4.5$ $\mathrm{g}$ of IV empirical piperacillin-tazobactam. Her left upper limb was elevated. No growth was observed in the wound culture. The dressings were changed on a daily basis. The superficial tissue USG performed on the dorsal aspect of her left hand indicated an abscess, which was drained by the Orthopedics department through a one $\mathrm{cm}$ incision made on the focus of the abscess. When the patient's discharge diminished and her infection symptoms regressed on the $10^{\text {th }}$ day of the treatment, the spectrum of the antibiotherapy was narrowed and the treatment was switched to $4 \times 1.5 \mathrm{~g}$ of IV ampicillinsulbactam. The necrotic tissue in the 3rd digit of the left hand was derided by the Plastic and Reconstructive Surgery department. On the $7^{\text {th }}$ day of the ampicillinsulbactam treatment, the patient was discharged with a prescription for $3 \times 1 \mathrm{~g}$ of cefazol and recommended daily dressing changes. A follow up visit was scheduled by the Plastic and Reconstructive Surgery department for the following week in order to close the tissue defect in the $3^{\text {rd }}$ digit of her left hand. Three weeks after her discharge, the patient was operated by the Plastic and Reconstructive Surgery department and the defect between the $3^{\text {rd }}$ dorsal proximal phalanx and the distal phalanx of the left hand was repaired with the flap elevated from her left femoral region.

\section{Discussion}

Human bites are potentially dangerous wounds constituting an important cause of morbidity (5). Although injuries due to human bites are rarely observed, they carry the greatest risk (10-50\%) for the development of infections (1). It is reported that infections that occur due to human bites are more dangerous than animal bites (1-3). Human saliva is 
known to contain 108 microbes $/ \mathrm{ml}$ and up to 50 different species of bacteria (6). This is the reason why the infection rates secondary to human bites are higher than other injuries (5). The most common bacteria blamed for the infections secondary to human bites are $\alpha$ and $\beta$ haemolytic Streptococci, Staphylococcus aureus, Staphylococcus epidermidis, Corynebacterium spp. and Eikenella corrodens (1). No bacterial growth was observed in the cultures obtained from our patients and this may be explained with the antibiotherapy the patients received before presenting to us.

Human bites are most commonly observed in the hands and wrists. In a study conducted on 388 patients, more than $50.3 \%$ of the patients were bitten on their hands or fingers, $23.5 \%$ were bitten on an extremity, and $17.8 \%$ were bitten on their head or neck (7). Besides infection, human bites may also result in tendon ruptures and even amputations. The ratio of amputations is reported between $7 \%$ and $20 \%$ in the literature (8). Both our patients were bitten on their toes and treated with the appropriate antibiotics after rinsing and debridement. Our second patient had to be operated due to the tissue defect located between the $3^{\text {rd }}$ dorsal proximal phalanx and the distal phalanx of her left hand and the defect was closed using the flap lifted from the left femoral region.

In patients at the early phase (the first 24 hours), those without concurrent diseases and without damage to the joint capsule or tendon injury, local wound care and treatment with oral broad-band antibiotics are reported to be adequate (3). In case of large or deep tissue injuries, systemic infection symptom or lack of response to the ambulant therapy, patients should be admitted to the hospital (9). Delays in hospitalizing the patient, performing the debridement or starting the IV antibiotherapy may worsen the treatment response $(10,11)$. In these kinds of infections, rest, elevation and immobilization should primarily be maintained, the infected tissues should be debrided and closed sections should be drained. In addition, the appropriate antibiotic treatment should be started according to the clinical manifestation and the culture results. The physiotherapy should be scheduled at the earliest convenience depending on the infection and the patient should be followed up in terms of hand functions $(9,10)$. In both the patients followed up at our clinic, IV antibiotic treatment was started at an early phase and debridements were performed before immobilization. The following reconstruction and physiotherapy led to satisfactory results.

\section{Conclusion}

Human bite wounds have long had a bad reputation for severe infection and frequent complication. For this reason, prophylactic antibiotic treatment should be given after human bite to prevent infection. If the infection signs and symptoms develop, rapid diagnosis, appropriate antibiotic and surgical therapy should be applied instantly.

Contributions: The authors contributed equally.

Ethical standards: The experiments comply with the current laws of the Republic of Turkey.

Informed Consent: Yes.

Peer-review: Externally peer-reviewed.

Conflict of Interest: No conflict of interest was declared by the author.

Financial Disclosure: The author declared that this study has received no financial support.

\section{References}

1. Griego RD, Rosen T, Orengo IF, Wolf JE. Dog, cat and human bites: a review J Am Acad Dermatol 1995; 33: 10191029.

2. Hausman MR, Lisser SP. Hand infections. Orthop Clin North Am 1992; 23: 171-185.

3. Zobowicz VN, Gravier M. Management of early human bites of the hand: a prospective randomized study. Plast Reconstr Surg 1991; 88: 111-114.

4. Clark DC. Common acute hand infections. Am Fam Physician 2003; 68: 2167-2167.

5. Pradnya d Patil, Tanmay $S$ Panchabhai and sagar $C$ Galwankar: Managing human bites. J Emerg Trauma Shock 2009; 2: 186-190.

6. Perron AD, Miller MD, Brady WJ. Orthopedic pitfalls in the ED: Fight bite. Am J Emerg Med 2002; 20: 114-117.

7. Merchant RC, Zabbo CP, Mayer KH, Becker BM. Factors associated with delay to emergency department presentation, antibiotic usage and admission for human bite injuries. Can J Emerg Med 2007; 9: 441-448.

8. Chadaev AP, Jukhtin VI, Butkevich AT, Emkuzhev VM. Treatment of infected clench-fist human bite wounds in the area of metacarpophalangeal joints. J Hand Surg Am 1996; 21: 299-303.

9. Wienert P, Heiss J, Rinecker H, Sing A. A human bite. Lancet 1999; 354: 572.

10. Phillip E, Wright $H$. Basic surgical technique and aftercare. In: Canale ST, Editor Campell's operative orthopedics. 9th ed. St. Louis: Mosby; 1998. 3273-3294.

11. Calandruccio JH. Amputations. In: Canale ST, editor. 
Campbell's operative orthopedics. 9th ed. St. Louis: Mosby; 1998. 3517-3548.

\section{How to cite?}

Ince FM, Aslan E, Deveci O, Tekin R. Soft tissue infections due to human bites. J Immunol Clin Microbiol 2016; 1(2): X-X. DOI: http://dx.doi.org/10.5455/jicm.2016.1.224190

Submit your next manuscript to the JICM and take full advantage of;

- Convenient online submission,

- Thorough peer review, Fast Response,

- No space constraints or color figure charges,

- Immediate publication on acceptance,

- Inclusion in Scopemed and High quality indexes,

- Research which is freely available for redistribution.

To submit your manuscript, please click on http://www.jiacm.com

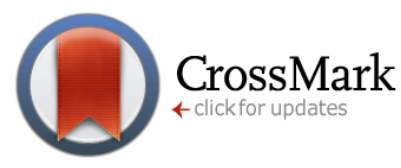

Published by The QMEL.org International Medical Education Library

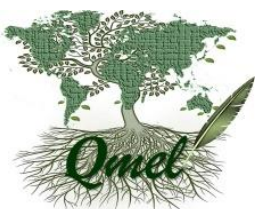

